\title{
Glinicopathological Studies of Latent Carcinoma of the Thyroid
}

\author{
Shinji TAKAHASHI \\ Department of Pathology I, School of Medicine, Iwate Medical University, Morioka, Japan. \\ (Director : Professor Kanichi Yagawa) \\ Department of Surgery I, School of Medicine, Iwate Medical University, Morioka, Japan. \\ (Director : Professor Kôichi Seta)
}

Neoplasms in thyroid gland, except anaplastic carcinoma, are well known to grow slowly in comparison with other carcinoma in the body.

Small and microscopic cancers removed at autopsy can be found incidentally in the thyroid glands of the subjects who suffered from various diseases. In 1960, Woolner et al. reported that $54(41 \%)$ out of 140 cases with occult papillary carcinoma were associated with nodal metastasis and 82 were found by chance in thyroid operations for some other diseases.

This report deals with "latent carcinoma of thyroid gland" which was found quite unitentionally in the thyroid gland showing no gross abnormality at autopsy.

The thyroid glands were removed from 320 subjects under routine consecutive postmorten examinations in the Department of Pathology of the Iwate Medical University and the Iwate Central Prefectural Hospital.

The following results were obtained. 44 cases with latent carcinoma (13.8\%) were found among 320 thyroid glands in the course of the examination of autopsy materials. In all patients clinical signs and symptoms of malignant changes in the thyroid gland, such as enlargement of thyroid gland and cervical lymph, nodes were not present at autopsy.

21 cases $(48 \%)$ were sclerosing carcinoma which is small tumors usually with dense fibrosis.

Papillary adenocarcinoma in which sclerosing appeared were found in 15 cases $(71 \%)$ and follicular adenocarcinoma were in 6 cases (29\%). In histological features (without a sclerosing), 16 cases $(70 \%)$ showed purely papillary adenocarcinoma, and 6 cases $(26 \%)$ showed purely follicular adenocarcinoma. One case showed dominantly trabecular.

The lesion varied from 3 to $10 \mathrm{~mm}$ in diameter. 36 cases $(83.7 \%)$ of latent carcinoma of the thyroid were smaller than $3.5 \mathrm{~mm}$ in diameter. 23 cases $(53.5 \%)$ in smaller size were under $1.5 \mathrm{~mm}$. Two cases showed as long as $10 \mathrm{~mm}$ in the diameter of latent carcinomas.

The youngest patient with papillary adenocarcinoma was 3 years old and the oldest was 66 years old. The incidence of papillary adenocarcinoma was highest among patients in the 40-59 year age group. Follicular adenocarcinoma ranged from 49 to 78 years of age, and was remarkably high when a subject was over 60 years old. The scle- 
rosing carcinoma was found in older age rather than the other histological types.

The distribution of the papillary adenocarcinoma by sex was 12 females and 19 males, and that of the follicular adenocarcinoma was 8 females and 4 males. In sclerosing carcinoma, 8 cases were male and 13 were female.

These latent carcinoma were located at the peripheral parts of the upper and lower pols of the lobe.

(See pp. 65 79) 


\section{潜在性甲状腺癌の臨床病理学的研究}

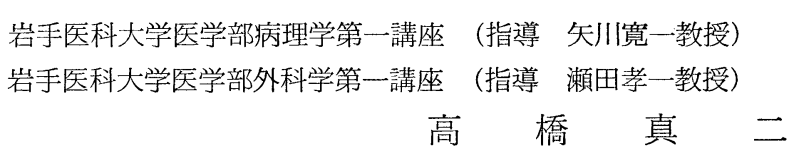

(昭和44年 1 月31日受付)

潜在性甲状腺癌の頻度および臨床病理学的特徵について研究した。臨床的にも肉眼的にも癌腫の存在 を明らかにしえなかつた 320 例の剖検例甲状腺を材料として連続薄切片を作り, 組織学的に精查した。 その結果 320 例中 44 例 $(13.8 \%)$ 亿潜在性癌を発見し，組織像では乳頭腺癌 31 例 $(70.5 \%)$ ，小胞腺癌 12例 $(27.3 \%)$ ，索状癌 1 例 $(2.2 \%)$ で，そのそち硬化癌21例からなる。甲状腺にはこれを精查すれば かなりの率に潜在性癌の存在するととを知つた。

\section{まえがき}

甲状腺の癌には他臟器のそれと同じ組織像をもちながら, はるかに緩慢な発育を示すものが多い．また先 ず転移巣に気づかれてから甲状腺原発癌が明らかになつたり, あるいは生前にはその存在に気づかれずに。 ほかの疾患で死亡し，剖検によりはじめて発見され

\section{るような微小な癌がある。}

著者は甲状腺癌を赤崎 ${ }^{1)}$ が提示した前立腺癌の臨 床病理学的分類にならつて, 臨床的顕性癌 clinical ly manifest carcinoma, 不顕性癌 occult carcinoma (潜在性活動癌)，および潜在性癌 latent carcinoma （潜在性非活動癌）とに分類した（Fig. 1)。このう ち潜在性甲状腺癌とは甲状腺自身には臨床的にも肉 眼的にも癌としての所見がなく，またそのほかの部 位にも甲状腺からの転移腫瘍か認妨孔れ゙, 組織学 的に精査してはじめて発見されるような微小な癌の ととである。

甲状腺の潜在性癌については $\mathrm{Graham}^{2)}$ が記載し て以来かなりの報告があるが，その組織像は多彩で あり,またその定義ないし用語の使い方, 頻度など も人により一定していない．特に剖検材料による甲 状腺潜在性癌の系統的研究は少なく，わが国ではほ とんどみあたらない.

そてで著者は剖検例の甲状腺を組織学的に精查し たとてろ，かなりの頻度に潜在性癌を発見するとと ができたので，その病理形態学的ならびに臨床病理 学的特徴について研究した。
Fig. 1. Clinicopathological Classification of the Thyroid Cancer

\section{1. clinically manifest carcinoma}
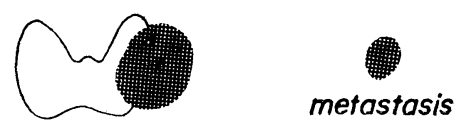

\section{2. occult carcinoma}
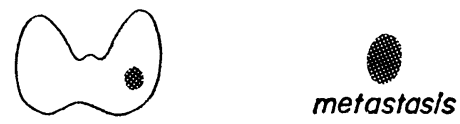

\section{3. latent carcinoma}

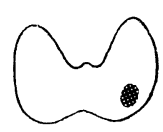




\section{研究材料および研究方法}

\section{1 研究材料}

1957年10月から1966年11月までの 9 年 2 カ月の間に岩手医科大学病理学教室で行なつた剖検例の中から 271 例，および岩手県立中央病院病理部での剖検例の中から 49 例，合計 320 例の甲状腺である．いずれも臨 床的ないし肉眼的外観像では癌などの特別異常所見は認められず，また死因や年令などを考虑しないで無撰 択的にとり出したものである.

\section{2 研究方法}

甲状腺組織はすべて前額面で約 $5 \mathrm{~mm}$ の厚さの組織片とし，各組織片についてまず肉眼的に精査した。そ てで若し周囲甲状腺組織と識別される微小結節や解痕様所見などがみい出されたときは，あらかじめ前額面 で投影した甲状腺の模式図に記載し，後に鏡検用の組織標本を作製した。すなわち 1 症例の甲状腺を 4 ない し 6 個のパラフィンブロックとし，さらに1個のパラフィンブロックを30枚の連続薄切片とした，染色はへ マトキシリン・エオジン，ワンギーソン，マロリーアザン，PAS，鍍銀（Pap 法）をほどてし，ときにムチ カルミン染色 (Mayer) なども加えた.

\section{研 究 成 績}

\section{1 潜在性甲状腺癌の病理形態学的所見}

\section{1) 肉眼的所見}

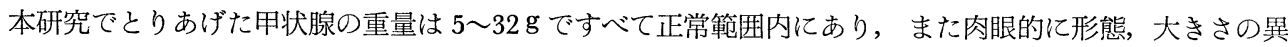
常を示すものはなかつた。

おのおのの症例の甲状腺について前述のでとく前額面で平行割面をつくり観察すると，大部分の症例では

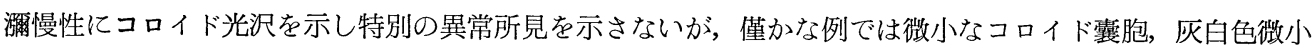
結節あるいは不規則般痕椂病巣などが認められた。てれらの肉眼的異常病巣のうち組織学的検索で, 癌であ るてとの判明したものについてみると，微小結節は円形，類円形のコロイド結節，充実性小結節，あるいは 紡鉦形の䑤痕様病巣としてみられるものが多かつた。このなかでも薄い被膜様構造の明らかなものと，てれ を欠いている場合とが存在した，被膜様構造をもつている小病巣の大部分は，肉眼的にコロイド霊胞か, 腺 腫のでとき外観を呈するが，肉眼的に灰白色病巣では結節と正常甲状腺組織との境界が不明瞭で悪性浸潤像 ともみられるものも存在していた。いずれにせよてれらの病巣を肉眼的に癌病巣と診断するてとは不可能で あつた (Fig. 2,3).

\section{2) 組織学的所見}

甲状腺癌の組織学的分類に関しては，Wilson ${ }^{3)}$ が甲状腺癌の組織像はきわめて多样性を示すてとから 23 種 もの形態学的分類をおてなつているでとく, 従来から臨床的あるいは病理組織学的立場から多数の, しかも 複雑多岥な分類がおてなわれてきている，さらに同癌病巣が 2 種あるいはそれ以上の組織像を呈するてとが しばしば認められ，その分類帰属に一層複雑さを加えている。

著者は最近, 矢川 ${ }^{45)}$ が UICG 甲状腺癌分類国内委員会に提示した甲状腺癌の病理組織学的分類に従つて, 潜在性甲状腺癌の分類を試みた（Table 1).

つぎ潜在性甲状腺癌の各種組織像について，著者が経験した代表的症例を示しながら述べてみるととに する。

\section{(1) 乳頭腺癌}

症 例：52才 男性 (SN. 2021)

臨床診断：胃癌

剖検診断：胃幽門部癌（腺癌）

胃小彎側に一致して，やや幽門よりに小児手缶大範囲に不規則丘状の肥厚を示す癌があり，その表面は全 
Table 1. Histological classification of thyroid cancer (by Yagawa)

Papillary adenocarcinoma

Sclerosing carcinoma $\left\{\begin{array}{l}\text { nonencapsulated } \\ \text { encapsulated }\end{array}\right.$

Follicular adenocarcinoma

Malignant adenoma (metastasizing struma)

Proliferating struma (Langhans)

Eosinophilic cell (Hürthle cell) carcinoma

Solid carcinoma

Trabecular carcinoma

Medullary carcinoma (Hazard) (Solid carcinoma with amyloid stroma)

Water clear cell carcinoma (Getzowa)

Anaplastic carcinoma

Giant cell carcinoma

Small cell carcinoma

Spindle cell carcinoma

Pleomorphic cell carcinoma

Squamous cell carcinoma

く粘膜䏢壁を失い，ほぼ中心部に拇指頭大の類円形の潰瘍を形成していた。

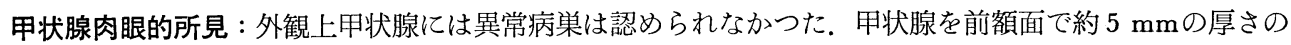
平行割面をつくると，右葉の狭部右側に長径約 $2.2 \mathrm{~mm}$ の 2 個の灰白色微小結節が認められた. このうち左 方の結節は境界明瞭であるが，乙れに隣接する右方の結節は境界が不明瞭であつた。いずれの病宩も肉眼的 に癌結節とは診断がつけられなかつた。

組織学的所見 : 上記の 2 個の灰白色微小結節の左側のものは菲薄な被膜様構造をもつているが一部で右側 の病巣と連なり，そてでは周囲の正常甲状腺組織に直接浸潤増殖を示していた. 左右の病巣とも著明な乳頭 状構造をとっており，その一部では大小の小胞を形成し，内腔に稀薄なコロイドを満しているものもみられ た．腫瘍細胞は好塩基性の胞体を有し円柱ないし立方形で，核は大小不同が目立ち円形あるいは類円形を呈 し，ところにより不整に丕んでいるものもみられ，クロマチンに富み，輪郭は明瞭であつた。

癌病巣以外の周囲甲状腺組織においては小胞間結合織が軽度増加し，ところどてろにリンパ球の巣状浸潤 がみられた (Fig. 4).

(2) 小胞腺癌

症例：79才 女性 (SN. 1865)

臨床彰断 : 盲腸癌, 術後イレウス

剖検診断 : 盲腸癌術後状態（腺癌）

大腸右半切除兼回腸横行結腸喘々吻合術後状態，十二指腸下行部の周囲癒着による狭窄状態.

甲状腺肉眼的所見：甲状腺は両葉とも大きさは正常であるが，右葉でほぼ中央部に小指頭大，結節状の軽 度隆起を認めた．割面で，その結節は長径 $6.3 \mathrm{~mm}$ で，外観筒形を呈した灰白色の充実性病巣を示す．境界 は鮮明で，明らかに周囲甲状腺組織と区別されるが被膜様形成は認められなかつた。

組織学的所見 : 組織学的にも周囲甲状腺組織とは境界明瞭であつて軽度圧迫して増殖しているのがみられ た. 腫瘍組織は小ないし中等度の管状ないし小胞状構造から成るが，著しく配列の乱れているとてろがある. 腫瘍細胞は立方形で，異型性に富んでおり，核は円形あるいは類円形を示しているが大小不同が著しかつた. 
癌病巣以外の甲状腺組織は小あいいは中等度の小胞から成るが，石灰化巣あるいはりンパ球浸潤などはみ られなかつた (Fig. 5)。

\section{（3）索状癌}

症 例: 46才 女性 (KSN. 191)

臨床診断 : 肝腫瘍

剖検診断 : 肝細胞癌

肝には小豆大からクルミ大の結節状癌組織が多数認められた.

甲状腺肉眼的所見 : 右葉の上極内側方に長径 $3.5 \mathrm{~mm}$ のやや不規則性の円形灭白色微小結節がみい出され た。この病巣が周囲甲状腺組織にむかつて結合織が星芒状にのびているような外観を示した．他には肉眼的 に瘢痕およびコロイド囊胞などの異常病変は認められなかつた。

組織学的所見 : 腫陽結節の中心部に不規則な星芒形を示した硝子様の間質がみられ，それを中心として索 状の配列を示す腫瘍実質細胞が充実性に増殖している。腫湯細胞は 4 ないし 5 列の索状配列をとり，周囲甲 状腺組織の中へ著明な浸潤性増㽝をおてしている。腫晹細胞は買型性に富み，核も大小不同が著しい。また とてろどてろに核分剖像が認められた。ところにより小胞構造を想められ，内腔にコロイドを容れている (Fig. 6).

\section{（4）硬化癌}

本腫瘍は硬い硝子様の結合織間質とてれに癌実質がいろいろな程度に組み合わさつて，いろいろな組織像 をとつてきているもので放射状に形成された胼胝状間質に沿つて腫愓組織が増殖しているもの（非被包性硬 化癌）と癌実質を硝子様の結合織が包囲し，乙の中で腫瘍細胞が不規則性に増殖しているもの（被包性硬化 癌）とに区別される。いずれにしても甲状腺における硬化癌という名称は従来から微小癌の形をとつたもの に用いられてきているものである。著者は久川 ${ }^{4)}$ の分類にならつて硬化癌を次の 2 型て分類した。

i ) 非被包性硬化癌

症例: 38才 女性 (SN. 1742)

臨床診断 : 両側腎結核および膀胱結核

剖検診断：両側眯結核，膀胱結核および卵巣結核

甲状腺組織所見：一見無構造の胼胝状間質が周囲甲状腺組織の小胞間に放射状にのび，その間質に密着す るように癌細胞か浮頭状配列を示して増殖していた (Fig. 7).

症例：52才 男性 (SN. 2055)

臨床䛦断 : 尿毒症

剖検診断：結発性腎硬化症

甲状腺組織所見：小胞閒に不規則放射状にのびた間質にとり囲まれるがでとく，腫瘍組織が小胞状構造を とつて增殖しているのが浔められた（Fig. 8).

ii）被包性硬化癌

症例: 58才 男性 (SN. 1711)

臨床診断 : 脳出血

剖検診断 : 脳出血（橋出血）

甲状腺組織所見：腫愓実質は硝子様胼胝状の結合織被膜で包囲され，乙の被膜の内側から内腔に向つて不 規則にのびた樹枝状結合織に沿つて乳頭状の癌が増殖しているのが認められた (Fig. 9).

症例: 46才 男性 (SN. 1897)

臨床診断 : 胃癌

剖検診断：胃癌（腺癌）

甲状腺組織所見 : 被膜内側に向つて不規則梁状に結合織がのびてれによつて小胞状の癌実質が分画される ようにして増殖を示すのが認められた（Fig. 10). 
非被包性硬化癌の組織像には被包性硬化癌と同じく, 乳頭腺癌と小胞腺癌とがあるが，前者の形を示すも のが多かつた。また被包性硬化癌においても乳頭腺癌の組織像をとるものが多かつた。

\section{2 潜在性甲状腺癌の発生頻度}

\section{1）潜在性甲状腺癌の剖検例における頻度}

岩手医科大学病理学教室の剖検例から，無撰択的にとり出された甲状腺材料は 271 例で，そのうち男性 155 例，女性 116 例で，潜在性甲状腺癌はそれぞれ 20 例 $(12.9 \%) ， 13$ 例 $(11.2 \%)$ と発見された。 また岩 手県立中央病院の剖検例からの甲状腺材料は男性 22 例，女性 27 例でそれぞれ 4 例 $(18.2 \%) ７$ 例 $(25.9 \%)$ に潜在性甲状腺癌がみいだされた。

以上を合計すると剖検例 320 例のうち44例 (13.8\%) 亿潜在性甲状腺嵒が発見されたととになる (Table 2).

\section{2）潜在性甲状腺癌の組織像別頻度}

潜在性甲状腺癌44例の組織像別頻度では乳頭腺癌16例 $(69.5 \%) ， 小$ 胞腺癌 6 例 $\quad(26.0 \%)$ ，索状癌 1 例 (3.5)\%，その他いわゆる硬化癌が21例 $(47.7 \%)$ みられた（Table 3)。硬化癌をさらに被包性と非被包性

Table 2. Incidence of latent carcinoma of thyroid glands removed at 320 consecutive routine necropsies

\begin{tabular}{|c|c|c|c|}
\hline & $\begin{array}{c}\text { Number of examined } \\
\text { material }\end{array}$ & $\begin{array}{l}\text { Number of cases of } \\
\text { latent carcinoma }\end{array}$ & $\begin{array}{l}\% \text { of latent carcinoma } \\
\text { in examined material }\end{array}$ \\
\hline \multirow{3}{*}{$\begin{array}{c}\text { Iwate medical } \\
\text { university }\end{array}$} & 271 & 33 & 12.2 \\
\hline & 155 & 20 & 12.9 \\
\hline & 116 & 13 & 11.2 \\
\hline \multirow{3}{*}{$\begin{array}{l}\text { Central prefectural } \\
\text { hospital in morioka }\end{array}$} & 49 & 11 & 22.5 \\
\hline & $\mathrm{m}$. & 4 & 18.2 \\
\hline & f. & 7 & 25.9 \\
\hline Total & 320 & 44 & 13.8 \\
\hline
\end{tabular}

Table 3. Histological classification of 44 latennt carcinomas in 320 consecutive necropsies

\begin{tabular}{|c|c|c|c|c|}
\hline Papillary adenocarcinoma & 16 & $(69.5 \%)$ & & \\
\hline Follicular adenocarcinoma & 6 & $(26.0 \%)\}$ & 23 & $(52.3 \%)$ \\
\hline Trabecular carcinoma & 1 & $(3.5 \%)$ & & \\
\hline Sclerosing carcinoma & 21 & & 21 & $(47.7 \%)$ \\
\hline Total & 44 & & 44 & \\
\hline
\end{tabular}

Table 4. Histological classification of sclerosing carcinomas

\begin{tabular}{c|cc}
\hline \hline Encapsulated & & \\
papillary adenocarcinoma & 7 & $(33 \%)$ \\
follicular adenocarcinoma & 3 & $(14 \%)$ \\
Non-encapsulated & & \\
papillary adenocarcinoma & 8 & $(39 \%)$ \\
follicular adenocarcinoma & 3 & $(14 \%)$ \\
\hline Total & 21 & $(100 \%)$ \\
\hline
\end{tabular}


とに分類すると，被包性で乳頭腺癌の組織像をとるものが 7 例（33\%），小胞腺癌が 3 例（14\%）であつた． また非被包性では乳頭腺癌が 8 例 $(39 \%) ， 小$ 胞腺癌が 3 例（14\%）みられた（Table 4).

以上の組織像を全症例についてまとめてみると, 乳頭腺癌31例（70.5\%）で潜在性甲状腺癌の大部分を占 めており，次いで小胞腺癌12例 $(27.3 \%)$ であつた（Table 5).

\section{3）潜在性甲状腺癌の年令別頻度}

潜在性甲状腺癌全体の年令別頻度についてみると，3才から78才におよび，年代別にみると50才代が12例 (27.3\%)，60才代が10例 (22.7\%)，30才代が 6 例（13.6)\%，70才代が 6 例（13.6\%)，20才代が 2 例 4.5 \%) および10才代以下が 1 例 $(2.2 \%)$ となつており，甲状腺の潜在性癌は 50 才および60才代核率であつた。 検索材料 320 例の各年代における潜在性癌の頻度は，20才代は 21 例の検索例中 2 例 $(9.5 \%), 30 才$ 代は41 例中 6 例 $(14.8 \%) ， 40$ 才代は 56 例中 7 例 $(12.5 \%) ， 50$ 才代は 54 例中12例 $(22.2 \%) ， 60 才$ 代は 37 例中10例 (27.0\%) および 70才代は 17 例中 6 例 $(35.2 \%)$ と加令と共に癌発生頻度も増加しているのが注目された (Table 6).

潜在性甲状腺癌の組織像と年令別頻度とをみると, 乳頭腺癌 31 例中 20 才代以下が 3 例, 30 才代が 5 例, 40 才代が 6 例，50才代が 9 例，60才代が 6 例，70才以上が 2 例であつて，30才〜60才代が約 $80 \%$ を占めていた。 小胞腺癌では 12 例中 49 才以下が 2 例, 50 才代が 3 例, 60 才代が 3 例, 70 才代が 4 例となつていて, 乳頭腺癌 に比べて高年首に偏し，50才代以後では加令とともに増加の傾向を示した (Table 7).

硬化癌についてその年令別頻度をみると 20 才代が 1 例, 30才代が 3 例, 40才代が 4 例, 50 才代が 5 例と加 令と共に增加の傾向にあるのが注目された (Fig. 11)。 また硬化癌の組織像と年令別頻度をみると，乳頭腺 癌は40才代および50才代に多く, 硬化癌以外の潜在性癌における乳頭腺癌と比べやや高令層に多く発生して いた．小胞腺癌の場合もやはり50才代以後の高令者に多くなつており，硬化癌以多のそれより高令層に多く みられた。もつとも硬化癌自身がその他の潜在性癌に比べて高令首に多くみられたてとは前述したとてろで

Table 5. Histological classification of 44 latent carlinomas in 320 Consecutive necropsies

\begin{tabular}{c|rc}
\hline Papillary adenocarcinoma & 31 & $(70.5 \%)$ \\
Follicular adenocarcinoma & 12 & $(27.3 \%)$ \\
Trabecular calcinoma & 1 & $(2.2 \%)$ \\
\hline Total & 44 & $(100 \%)$ \\
\hline
\end{tabular}

Table 6. Age Incidence of latent carcinomas in the all cases

\begin{tabular}{c|c|c|c}
\hline Age group & $\begin{array}{c}\text { No. of examined } \\
\text { material }\end{array}$ & $\begin{array}{c}\text { No. of cases of } \\
\text { latent carcinoma }\end{array}$ & Per cent \\
\hline $1-19$ & 11 & 1 & 9.0 \\
$10-19$ & 79 & 0 & \\
$20-29$ & 21 & 2 & 9.5 \\
$30-39$ & 41 & 6 & 14.8 \\
$40-49$ & 56 & 7 & 12.5 \\
$50-59$ & 54 & 12 & 22.2 \\
$60-69$ & 37 & 10 & 27.0 \\
$70-79$ & 17 & 6 & 35.2 \\
$80-$ & 4 & 0 & \\
\hline Total & 320 & 44 & 100 \\
\hline
\end{tabular}


Table 7. Incidence of latent carcinomas of thyroid glands

\begin{tabular}{|c|c|c|c|c|c|c|}
\hline \multirow[t]{2}{*}{ Age group } & \multicolumn{2}{|c|}{ Papillary adenocar. } & \multicolumn{2}{|c|}{ Follicular adenocar. } & \multicolumn{2}{|c|}{ Trabecular carcinoma } \\
\hline & male & femal & male & femal & male & femal \\
\hline $1-9$ & 1 & & & & & \\
\hline $20-29$ & 1 & 1 & & & & \\
\hline $30-39$ & 2 & 3 & & 1 & & \\
\hline $40-49$ & 3 & 3 & & 1 & & \\
\hline $50-59$ & 7 & 2 & 2 & 1 & & \\
\hline $60-69$ & 4 & 2 & 1 & 2 & & 1 \\
\hline $70-79$ & 1 & 1 & & 4 & & \\
\hline \multirow{2}{*}{ Total } & 19 & 12 & 3 & 9 & & 1 \\
\hline & \multicolumn{2}{|c|}{31} & \multicolumn{2}{|c|}{12} & \multicolumn{2}{|c|}{1} \\
\hline
\end{tabular}

Fig. 11. Age Incidence of Latent Garcinomas

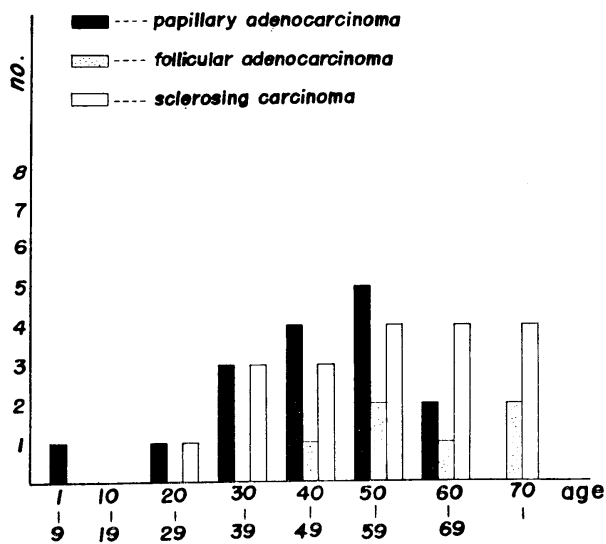

Fig. 12. Diameter and Number of Latent Carcinoma

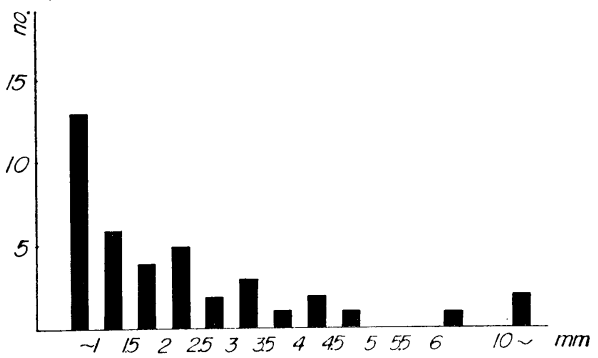

ある。

\section{4）潜在性甲状腺癌の性別頻度}

潜在性甲状腺癌44例中男性が22例 $(50.0 \%)$ ，女性が22例 $(50.0 \%)$ で両者が相半した。

男女別の年代首から潜在性癌の頻度をみると，男性は50才代 9 例 $(40.9 \%)$ を高率とし，若年層から50才 代に階段状に増加しているのに比へ，女性では30才代 4 例（18.1\%）および40才代 4 例（18.1\%）を低率と し男性と同様に加令と共に増加を示していた.

\section{3 潜在性甲状腺癌の大きさ}

1）潜在性甲状腺癌の大きさ

肉眼的に始めから癌腫と診断されたものはほとんどなく，組織学的に精査して始めて癌腫に気づいたよう な微小なものが大部分であつた。

潜在性甲状腺癌全体についてみると，直径が $3.5 \mathrm{~mm}$ 以下のものが36例（82\%）で10 mm以上のものは僅 か $(10.0 \mathrm{~mm}$ と $12.2 \mathrm{~mm})$ の 2 例にすぎなかつた. 以上のように潜在性癌の多くは非常に微小な癌病巣であ つてよほど注意して検索しないと見落とされ易いものである (Fig. 12).

組織像別から病巣の大きさを検討してみると, 乳頭腺癌の最長径は $2.2 \mathrm{~mm}$, 小胞腺癌は $6.3 \mathrm{~mm}$ であつ 
た. また硬化癌で乳頭腺癌の最長径は $12.2 \mathrm{~mm}$ で, 小胞腺癌は $10.0 \mathrm{~mm}$ であつた.

\section{2）癌の大きさと年令との関係}

潜在性甲状腺癌は加令と共に増加の傾向にあつたが，特別高令層に大きな癌腫が存在するとは限らず，潜 在性癌の大きさと年令との間には明らかな相関関係はみい出すととはできなかつた (Fig. 13).

\section{4 潜在性甲状腺癌の甲状腺内分布}

甲状腺癌の発生部位を甲状腺の前額面に投影した模式図に図示すると，両葉とも上極および下極で，しか も比較的辺縁部に寄つて発生しているのが認められた (Fig. 14).

Fig. 13. Scattergram Showing Relationship of Age and Diameter in Latent Carcinoma of Thyroid Glands

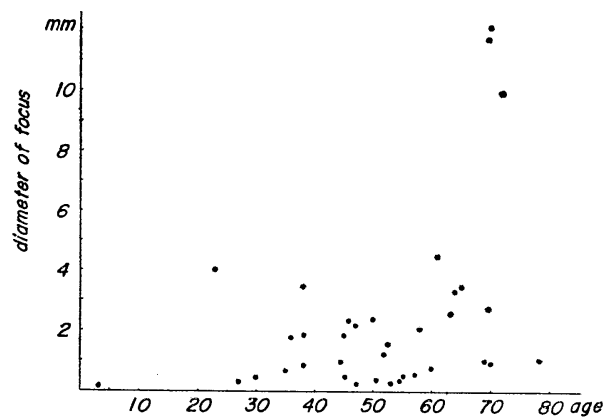

Fig. 14. Distribution of Latent Garcinomas

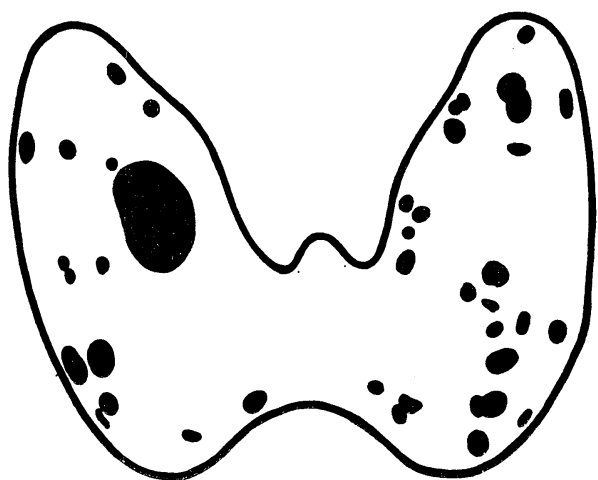

1 個の甲状腺に 2 個以上の癌病巣をみい出したものが乳頭腺癌に 3 例, 小胞腺癌に 1 例, 合計 4 例に存在 した。、いずれも微小な癌病巣で, 組織像は同じであるが, それぞれ全く別個に存在し多中心性発生と考元ら れるものであつた.

\section{5 潜在性甲状腺癌の間質について}

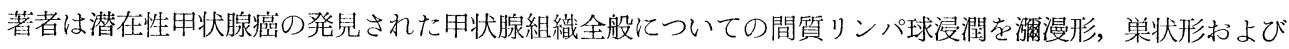
濾胞形（牙中心形成）と区別した。間質のリンパ球浸潤はすべて乳頭腺癌のみに見られ，すなわち乳頭腺癌 31例中 6 例 $(19.3 \%)$ に認められた。 またリンパ球浸潤はいずれも濔漫形および巣状形であつた．橋本病に おいてみられるごとき小胞の萎縮，上皮の変性腫大と好酸性化などの像はみられなかつた。

癌病巢以外の甲状腺小葉間における結合織增加の態度をみると, 線維が甲状腺組織全般へ源漫性にあるい は限局性に増加しているものがあり, 乳頭腺癌および小胞腺癌では濔漫性に増加している例が多いのに比べ， 硬化癌では限局性に硝子様ないし胼胝状間質が増殖している傾向がみられた。

石灰沈着に関しては，硬化癌のうち特に被包性のものの被膜様結合織内に不規則雲祭状の石灭沈着が観察 された．その頻度は硬化癌21例中 6 例 $(28.5 \%)$ であつた. さらに同心円性層板状構造をもち，直径約20〜 $70 \mu の わ ゆ$ calcospherite (psammoma body) が被包性硬化癌で乳頭腺癌の像を示した 1 症例にみら れたにすぎない (Table 8).

\section{6 潜在性甲状腺癌亡他臓器の原発性悪性腫瘍との関係}

検索剖検材料 320 例中，悪性腫焬で死亡した症例数は 119 例であつた。 そのうち潜在性甲状腺癌と他藏器 の原発性悪性腫瘍との重複例は23例 $(19.3 \%)$ 亿存在した.

重複腫瘍例における甲状腺癌以外の墨性腫瘍についてみると胃癌 7 例, 結腸癌 3 例, 腎癌 3 例, 直腸癌, 皮膚癌および子宮癌各 2 例, 食道癌, 肝癌, 肺癌および乳癌各 1 例であつた。特に男性では胃癌, 女性では 子宮癌および消化器系の癌腫との重複例が多かつた。性別では男性 9 例, 女性14例で, その平均年令はそれ ぞれ54才および52才であつた (Table 9). 
Table 8. Histologic nature of thyroid stroma in patients with clinically normal thyroid glands

\begin{tabular}{|c|c|c|c|c|c|}
\hline \multirow{2}{*}{ Type of malignancy of thyroid } & \multicolumn{2}{|c|}{ Lymphocytic infiltratison } & \multirow{2}{*}{$\begin{array}{c}\text { Calcification } \\
\text { (psammoma body) }\end{array}$} & \multicolumn{2}{|c|}{ Fibrosis } \\
\hline & focal & diffuse & & focal & diffuse \\
\hline Papillary adenocarcinoma & 3 & 1 & 0 & & 7 \\
\hline Follicular adenocarcinoma & 0 & 0 & 0 & & 4 \\
\hline Trabecular carcinoma & 0 & 0 & 0 & & 0 \\
\hline \multicolumn{6}{|l|}{ Encapsulated } \\
\hline papillary adenocarcinoma & 1 & 0 & $3 \quad(1)$ & 2 & 5 \\
\hline Follicular adenocarcinoma & 0 & 0 & 2 & & 1 \\
\hline \multicolumn{6}{|l|}{ Nonencapsulated } \\
\hline papillary adenocarcinoma & 1 & 0 & 0 & 2 & 6 \\
\hline Follicular adenocarcinoma & 0 & 0 & 1 & 1 & 2 \\
\hline Total & \multicolumn{2}{|c|}{6} & $6 \quad(1)$ & \multicolumn{2}{|c|}{32} \\
\hline
\end{tabular}

Tacle 9. Carcinoma of thyroid glands associated with other primary malignant tumors

\begin{tabular}{l|r|r|r}
\hline \multirow{2}{*}{$\begin{array}{c}\text { Site orig. of } \\
\text { primary carcinoma }\end{array}$} & $\begin{array}{c}\text { No. of cases } \\
\text { with cancer }\end{array}$ & \multicolumn{2}{|c}{$\begin{array}{c}\text { No. of cases with latent } \\
\text { carcinoma of thyroid }\end{array}$} \\
\hline \hline Oesophagus & 7 & male & female \\
Stomach & 38 & 5 & 0 \\
Colon & 7 & 1 & 2 \\
Rectum & 6 & 0 & 2 \\
Liver & 5 & 0 & 2 \\
Lung & 20 & 1 & 1 \\
Skin & 2 & 1 & 0 \\
Kidney & 6 & 0 & 1 \\
Breast & 8 & 0 & 1 \\
Uterus & 20 & 9 & 14 \\
\hline \multicolumn{1}{c}{ Total } & 119 & & $(19.3 \%)$ \\
\hline
\end{tabular}

Table 10. Gause of death of patients with latent carcinoma who died of other diseases

\begin{tabular}{l|c|c|c}
\hline & $\begin{array}{c}\text { Number of examined } \\
\text { material }\end{array}$ & $\begin{array}{c}\text { Number of cases of } \\
\text { latent carcinoma }\end{array}$ & $\begin{array}{c}\% \text { of latent carcinoma } \\
\text { in examined material }\end{array}$ \\
\hline \hline Malignant tumor & 119 & 23 & 19.3 \\
Cerebral haemorrhage & 17 & 6 & 35.2 \\
Inflammatory disease & 36 & 10 & 13.8 \\
Other disease & 14 & 44 & 31.7 \\
\hline Total & 320 & 100 \\
\hline
\end{tabular}


なおその他の病変との関係についてみると，脳血管障害例 17例中 6 例 $(35.5 \%)$ ，炎症性疾患の剖検例 36 例中 5 例 $(13.8 \%)$ 飞潜在性甲状腺癌が発見された（Table 10).

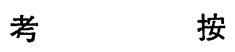

\section{1 潜在性甲状腺癌の定義}

潜在性甲状腺癌の概念は，側迷入甲状腺腫について一歩前進した Wozenkraft (1948) ら cinoma of the thyroid”の記載にはじまるが，すでに Garham (1907) ${ }^{2)}$ は甲状腺機能元進症の甲状腺腫に 合併した微小な甲状腺癌について報告している.

甲状腺の微小癌には研究者によりいろいろの名称でよばれているものが含まれている．剖検で偶然に発見 された微小な原発性甲状腺癌について，赤崎 ${ }^{7)}$ は顕微鏡的甲状腺癌，平間 ${ }^{8)}$ は初期甲状腺癌という用語を用 いている. Woolner $ら^{9)}$ は $1.5 \mathrm{~cm}$ 以下の甲状腺乳頭腺癌を occult papillary carcinoma, Reed ${ }^{10)}$ は tiny sclerosing follicular carcinoma とよび，また甲状腺癌以外の甲状腺疾患で手術された手術材料を検索して 発見された微小な癌に関しては, Graham ${ }^{2)} は$ adenocarcinoma not originating in adenoma. Geotsch ${ }^{11)}$ は carcinomatous lesions occuring in hyperplastic thyroid, Wozenkraft $ら^{6}$ は occult carcinoma, Hazard ${ }^{12)}$ は nonencapsulated sclerosing tumor, Minder ${ }^{13)} は$ Sklerosierendes Mikrokarcinom Klink $ら^{14)}$ occult sclerosing carcinoma という名称で呼びおのおのの自験例について報告している.

著者が潜在性甲状腺癌 (latent carcinoma) としてのべたものは，まえがきの項で述べたでとく赤崎 ${ }^{1)}$ が 示した前立腺癌の臨床病理学的分類にならつたもので, 甲状腺には原発性甲状腺癌としての臨床症状および 肉眼的所見を欠き, また甲状腺癌の存在を疑わせるような転移も存在せず, 組織学的に検索して始めて発見 されるような微小な原発性甲状腺癌である。ちなみにリンパ節ないし他蔵器への転移に先ず気ずかれて後発 見されたような原発性甲状腺癌は不顕性癌 (occult carcinoma), また明らかに甲状腺癌としての臨床症状 をもつて診断されたものを顕性癌 (clinically manifest carcinoma) と呼ぶてとは前述の通りである.

しかし従来は著者の述べる潜在性癌と不顕性癌の両者が特に区別されずに微小癌として論じられている場 合が多く, 著者もとてで両者をあわせて微小癌と呼ぶことにした。もつとも戦密な意味では微小癌はその大 きさが微小でさえあれば, 必ずしも潜在性癌ないし不顕性癌でなくともよいわけである。すなわち微小癌の 範疇に入るような小さな癌でも甲状腺の表面近くに位置すれば顕性癌の像を示すてともありうる，そてで甲 状腺微小癌の大きさについては明瞭な限界があるわけではなく, また癌病巣が同じ大きさでも甲状腺の深部 ないし中心部に位置するか, あるいは浅在ないし表在するかによりその肉眼ないし触診所見を異にするてと は当然のてとである。ただ経験的に甲状腺内におよそ直径 $1.5 \mathrm{~cm}$ 以上の癌病巣があれば触知可能であり, ま たそれ以下の小さい癌は治療により完全治癒が期待されるととから, 一般的に微小癌としてとりあげられて いるものはおよそ直径 $1.5 \mathrm{~cm}$ 以下のものである.

\section{2 潜在性甲状腺癌の病理形態学的所見}

甲状腺の大きさ：甲状腺の大きさは年令，性，および人種，気候，風土などの地理的環境によつて差があ るが，その重量は35才頃迄に増加を示し，老年期になるにつれ軽度減少を来す．Hellwig ${ }^{15)}$ にると平均甲

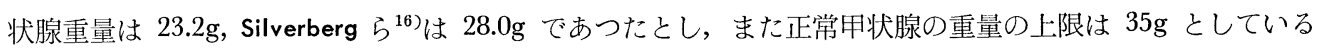
学者が多い ${ }^{17) 1832)}$. 著者の剖検例による甲状腺の最高重量は $32 \mathrm{~g}$ で, いずれも正常範囲内で, 甲状腺腫を 疑わしめたものは存在しなかつた。

潜在性甲状腺癌の肉眼的所見 : 潜在性甲状腺癌のうち肉眼的に認めうるものでは腫瘍の輪郭が比較的鮮明 なもの, 不規則不鮮明なものあるいは線維性被膜によつて被包性にみえるものなどいろいろあり, 形も円形, 類円形あるいは不規則多稜形ないし星芒状などを示し, 色も白色から灰白色と多彩である ${ }^{10) 12(19)}$. またしば しば石死沈着を伴つているととが報告されている ${ }^{20)}$.

著者の検索例においても同じく多種多様であるが，大部分が微小な疲痕様病巣としてみられ，甲状腺の被 膜に近接あるいは甲状腺の表面に近く存在する場合は，甲状腺が臍窩状に表面から陷凹しているてとが多い. 
割面では灰白色ないし焱黄色の，不規則星芒状ないし類円形を示すととが多い．

潜在性甲状腺癌の組織学的所見 : 潜在性甲状腺癌は線維性ないし硝子様の間質が腫憆実質を梁状に分画し たり，またてれらの間質に接して腫湯細胞が增殖しているのが特徴であるとのい゙ているものが多い．また腫 瘍実質は乳頭状，小胞状あるいは両者が混在するものなどがあるが，乳頭腺癌がその大部分を占めていると 報告されている ${ }^{910) 211}$. 特に著明な結合織增殖を伴つているものを Hazard $ら^{199}$ は nonencapsulated sclerosing tumor, Klinck $~^{14)}$ は occult sclerosing carcinoma とよび，てれらの名称で腄瘍の形態的特徴を如実に 表現している。矢川および桑田ら ${ }^{22233}$ は甲状腺腫煬の実質と間質との関係に注目し詳細に報告しているが, 著者は微小癌であつて著明な間質增殖を伴つたものを硬化癌という名称で総括した。ささらに腫瘍組織が間質 の周辺から周囲正常甲状腺組織内に浸潤性に增殖しているものを非被包性硬化癌, 間質によつて腫瘍実質が 包囲されているものを被包性硬化癌とよんだ。ただ被包性のものは Hazard ら ${ }^{19}$ も指摘しているでとく少な いものである.

甲状腺癌の組織学的診断は他藏器の癌の場合に比べ困難な場合が多い，矢川 ${ }^{24)}$ は甲状腺癌の初期像とみな される微小癌について報告しているが，悪性を規制する組織学的判定基準として，他藏器における癌の場合 と同じく原則的には，腫場細胞の大きさ，胞体汇対する核の大きさの比抢よびその形，染色性の不同，核分 剖像の存在，腫瘍細胞の配列の乱れ，被膜あるいは血管への浸襲像および転移を挙げている。Batsakis は ${ }^{20)}$ calcospherite の存在が，悪性腫瘍としての有力な組織所見であるとし，207例の甲状腺癌中84例 $(41 \%)$ 亿， また Klinck ら ${ }^{25}$ は は473例の甲状腺癌のうち277例 $(48 \%)$ 飞 calcospherite を発見したとのべている. 特に乳 頭腺癌の $50 \sim 60 \%$ にての小体力認められている。.さらに Underwood ${ }^{26)}$ は乳頭状構造を示す腫瘍において calcospherite の存在は，その病巣が悪性である証拠であると極言している。なお頸部りンパ腺転移をおて してきた症例ではその転移巣においても calcospherite を高率に認めている学者もある199. 確かに悪性甲状 腺腫ではこの calcospherite 亿遭遇するてとがしばしばであつて，甲状腺癌の組織学的診断にあたり有力な 参考所見になりうる ${ }^{27) 282299}$ ，しかし良性甲状腺腫煬においても石灰沈着を伴うことがあり，他方甲状腺癌に おいててれをみないものも決して少なくない，著者の潜在性甲状腺癌の症例においても，石灰沈着は硬化癌 21 例中 6 例に, また calcospherite は乳頭腺癌の組織像を示した被包性硬化癌の 1 例にてれを認めた。

\section{3 潜在性甲状腺癌の頻度}

従来剖検材料における甲状腺の検索は軽視される傾向にあり，剖検記録における甲状腺についての記載は Silliphant $ら^{30}$ によると $38 \%$ ，Schlesinger ら ${ }^{31)}$ は63\%にすぎなかつたとしている。したがつて剖検例による 潜在性甲状腺癌の研究もきわめて少い，また前述のでとく潜在性癌のわくずけは人により異なり, 検索の対 象ないし方法も区々で，一様に比較検討することは困難である。剖検例甲状腺を材料とした潜在性甲状腺癌 の系統的検索成績をみると Hull ${ }^{18)}$ は剖検例全体の $1.4 \%$, Silverberg $ら^{16)}$ は $1.8 \%$, Mortensen $ら^{33}$ は 2.8 \%および Crile ら ${ }^{28}$ は $3 \%$ と報告している。笹野ら ${ }^{34)}$ は甲状腺癌17例の剖検例老検討し，臨床的に甲状腺原 発癌と診断されたものは半数にすぎなかつたとし，さらに3例は剖検によつて偶然に発見されたものである と述べている．また最近 Sampson ら $^{35}$ は広島，長崎の剖検例甲状腺材料について，著者らと同じ方法て検 索し15\%以上の高率に甲状腺癌を発自している，以上のてとは原発巣がきわめて微小なてとがその理由の一 つであるとも考えられる. Silliphant $ら^{30}$ 亿よると甲状腺癌 193例のうち，90例（47\%）は剖検時にとり出さ れた甲状腺を組織学的に検索して始めて発見されたものであり，甲状腺癌が淔接死因となつたものは94例 (49\%) 亿すぎなかつたと述べている。著者の連続切片るよる検索では $13.8 \%$ と高頻度に微小な甲状腺癌を 発見した。 また肉眼的に異常病巣か認められなかつた一見正常の甲状腺にもかなりの高頻度に潜在性癌が存 在しているてとが明らかとなつた。すなわち病理組織学的検索が不充分であるてとが甲状腺癌の実際の発生 頻度と臨床的発生頻度との間に大きな差異をもたらしめている原因であると述へている学者もあり, 診断技 術の進歩とともに病理組織学的検索の普及徹底によつてその頻度はさらに増加するものと思われる。

\section{4 潜在性甲状腺癌の年令および性別頻度}

潜在性甲状腺癌の平均年令は Klinck ら ${ }^{14)}$ は48才，Woolner $ら^{99}$ は45才であり，また不顕性癌の平均年令は 
それぞれ44.5才，34才であつたとのべており潜在性癌と不顕性癌との年令的差異はなく, また年令と癌病巣 の大きさとも関係がなかつたとしている，著者の症例においても年令と癌病巣の大きさとの間には関係はみ い出せなかつた。

潜在性甲状腺癌と性との関係は70ないし80\%が女性で，しかも女性の平均年令は男性に比較し若年圏に発 生している，しかし Silliphant $ら^{30}$ は潜在性癌は男性に発生頻度が高かつたと報告している。

著者の例では性別による発生頻度は両性とも同じ頻度を示していた。もつとも性頻度は検索材料の選択方 法や症例数によつても影響されるものと思われる.

\section{5 潜在性甲状腺癌の大きさ}

甲状腺癌の発育は, 未分化癌は別として, 特に乳頭腺癌はきわめて緩慢で, 臨床症状が軽微で癌結節が小 さなうちに発見されるととが比較的多い ${ }^{36)}$. Frazell ら ${ }^{37}$ は乳頭腺癌の $15 \%$ が直径 $1 \mathrm{~cm}$ 以下であつたとし, Hazard ら ${ }^{19)}$ は25\%が直径 $1.5 \mathrm{~cm}$ 以下で, さらにてのうち $1 \mathrm{~cm}$ 以下が $16 \%$ 占めていたと述べている。すな わち甲状腺癌, 特に乳頭腺癌には微小で潜在性癌の形をとるものがかなりの頻度にあるてとが想像される.

Woolner $ら^{99}$ は Mayo Clinic で30年間に治療した約 690 例の乳頭腺癌のうち 140 例が潜在性ないし不顕性癌 であつたと報告しているが，てれらの大きさについてみると潜在性癌では直径 $1 \mathrm{~cm}$ 以下か $88 \%$, 不顕性癌 では直径 $1 \mathrm{~cm}$ 以下が87\%で，全体の平均が直径 $0.76 \mathrm{~cm}$ であり，大きさについては潜在性癌と不顕性癌と の間に有意な差はみられなかつたと述べている。また潜在性癌の大きさに関して Klinck ${ }^{14)}$ は直径 $1 \mathrm{~cm}$ 以下, Minder ${ }^{13)}$ および Hazard $~^{19)}$ はともに直径 $1.5 \mathrm{~cm}$ 以下に限定している.

著者の潜在性癌の症例のうち甲状腺割面で肉眼的に癌結節と疑われた病巣の最大㨁径は $12.2 \mathrm{~mm}$ で, 大部 分は組織学的に検索して始めて発胃された微小な癌病巣である.すなわち值烽が $3.5 \mathrm{~mm}$ 以下の病单が36例 $(81.8 \%), 1.5 \mathrm{~mm}$ 以下が23例 $(52.3 \%)$ ，また $10 \mathrm{~mm}$ 以上のものが 2 例に認められた. 以上のように潜在 性癌の大部分はきわめて微小なものであつて, その検索にあたつては十分な注意が必要である.

\section{6 潜在性甲状腺癌の甲状腺内分布}

潜在性甲状腺嵒の甲状腺内分布は両葉の上極および下極に多く, 特にその比較的周辺部に好発していた。

\section{7 甲状腺微小癌とリンパ節との関係}

頸部リンパ節および遠隔転移楽から始めて発兒された微小な原発性甲状腺癌, すなわち不顕性癌とりンパ 節転移との関係についてみると，Klinck $\left.{ }^{14}\right)$ は微小癌32例中10例 $(31.3 \%)$, Woolner ${ }^{9}$ は 56 例中 13 例 (23 \%) に頸節リンパ節転移を認めている。臨床的に乳頭腺癌と診断されたいわゆる顕性癌のリンパ節転移の発 生頻度をみるとCrile ${ }^{34)}$ は $75 \%$, Hazard ら ${ }^{39}$ は $54 \%$ ，また Beahrs ${ }^{40)}$ は47\%で，てのうち $1 \mathrm{~cm}$ 以下の癌病 单で転移を認めたものは央に $38 \%$ と報告している。乳頭腺㴦の多くは緩慢な発育增殖を示しながらリンパ行 性に転移をおこしてくることは周知のとてろである. Reed ら ${ }^{10}$ は闰肺野に異常病巣を認めた66才の男子の頸 部リンパ節を摘出したところ甲状腺からの転移と判り，甲状腺全剔出術を行ない，てれを連続薄切片で精査 して微小な硬化性小胞癌 (sclerosing follicular carcinoma) を発見している。また Gikas ${ }^{41)}$ は長径 $0.6 \mathrm{~mm}$ の潜在性乳頭腺癌からの頸部リンパ節転移例を報告している.

リンパ節転移と腫愓実質および周囲甲状腺組織との境界領域における浸潤程度との関係についてみると, 癌組織の浸潤程度が25\%以下のものはその頸部リンパ節転移が 4\%，25\%から50\%では14\%，50\%から75\% では $80 \%$ 認められ，原発癌組織の周囲甲状腺組織への浸潤程度が転移と密接な関係のあることを述べてい る学者もある ${ }^{12} 42$.

著者か溌見した微小な癌では，その大部分において程度の差はあるが浸潤像をみた。しかしリンパ節転移 をみい出したものはなく，潜在性甲状腺癌とみてよいものであつた．ただリンパ節の検索は主として肉眼的 所見によるものであつて, 組織学的微小転移をも考慮するとリンパ節転移との関係については充分論及する ことはできない.

\section{8 潜在性甲状腺癌と他臓器の原発性悪性腫瘍}

潜在性甲状腺癌の発見された症例の剖検診断についてみると, 他藏器の悪性腫瘍と共存した多発性原発性 


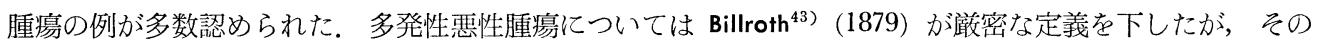
後幾多の変遷をたどり現在では Warren ${ }^{44)}$ (1932) の修正した定義が一般に受けいれられている。すなおち 個々の腫瘍は明らかに組織学的悪性像をもち。しかも別個の腫瘍の腫場であつて他の腫瘍からの転移病巣で

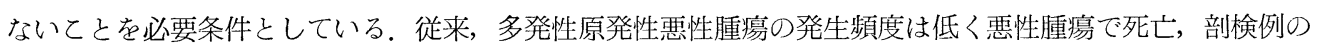
$1 〜 7 \%$ 報告している ${ }^{45)}$. さらに Pickren ${ }^{46)}$ は悪性腫愓の剖検例の $11 \%$ が多発性の悪性腫暘をもち，ての うち臨床的にも多発性原発癌と認められたものは7.7\%に達していたという。

最近における甲状腺癌の増加につれ, 悪性腫崲との重複発生症例の報告例も増加を示してきている. Moertel ${ }^{47)}$ は Mayo Clinic で経験した 309 例の悪性腫愓の剖検例において，33例（10.6\%）に状腺癌が 認められたと報告している，甲状腺癌と他臟器の悪性腫瘍との結み合せについてみると， Shimaoka ら ${ }^{48) の ~}$ 14例の多発性悪性腫瘍例では, 乳癌との重複例が 4 例 $(28.4 \%)$ と多く, さらに Moete ${ }^{47}$ の甲状腺癌との 多発性原発性悪性腫瘍の統計では乳癌との重複例が 7 例（21.2\%）を占めていたと報告している。般に甲 状腺癌が女性に多発しているのに鑑み，女性ホルモン代謝異常あるいはホルモン依存癌としての立場からも 考慮されるべき問題があるようにも思われる。Toylor ${ }^{499}$ は原発性乳癌と共存した他の藏器の原発癌18症例に ついて，その $5.5 \%$ \%性々器癌と関係のあるととを示し，また Huber ${ }^{50)}$ は75例の性器外癌のうち 30 例 (40.0\%) か浮癌であつたとのべている.

著者の多発性悪性腫愓23例のうち14例は女性で, しかもその3例（21.4\%）方浮癌および子宮癌であり女 性のホルモン代謝異常関連性があるようにみえた。

\section{ま と め}

著者は岩手医科大学病理学教室および岩手県立中央病院における, 過去 9 年 2 力月の間の剖検材料から無 撰択的にとり出した 320 例の甲状腺組織を病理組織学的に精査した。その結果44例（13.8\%）の潜在性甲状 腺癌を発見し次のでとき知見を得た。

（1）甲状腺検索材料 320 例中 44 例（13.8\%） 亿潜在性甲状腺癌か溌見された.

（2）潜在性甲状腺癌の大きさは直径 $0.12 \sim 12.2 \mathrm{~mm}$ であつた，元のうち長径 $3.5 \mathrm{~mm}$ 以下のものが 36 例 $(81.8 \%)$ で潜在性甲状腺癌の大多数を占め, さらに $1.5 \mathrm{~mm}$ 以下の癌病巣は23例 $(52.3 \%)$ であつた.

(3) 潜在性甲状腺癌の罹患年令と癌病巣の大きさとの関係については有意の差は認められなかつた.

(4) 病理組織学的には乳頭腺癌16例 (69.5\%), 小胞腺癌6例 (26.0\%) および索状癌 1 例 (3.5\%) で, その他にいわゆる硬化癌が 21 例存在した，硬化癌 21 例の組織像は乳頭腺癌 15 例 $(71.4 \%)$, 小胞腺癌 6 例 $(28.6 \%)$ であつた。いずれも乳頭腺癌が約70\%を占めていた。

（5）潜在性甲状腺癌の組織像の年令別頻度では乳頭腺癌は 3 才から 66 才におよび，30才代から50才代に多 く，小胞腺癌は49才から 78 才におよび50才代に多発していた。 またいわゆる硬化癌では乳頭腺癌が40才およ び50才代に多く，小胞腺癌は 50 才代以後の高令者に多く認められた，以上のでとく乳頭腺癌は若年者の方に 小胞腺癌, 特に硬化癌は高令者の方に多い傾向を示した.

（6）性別頻度では乳頭腺癌は男性19例, 女性12例で男性に多く, 小胞腺癌は男性 3 例, 女性 9 例で逆に女 性に多く認められた。

（7）潜在性甲状腺癌の甲状腺内分布は両葉の上極および下極に多く, 特にその比較的周辺部に好発してい た.

（8）潜在性甲状腺癌の発見された甲状腺組織の間質についてみると，リンパ球浸潤は 6 例 $(13.6 \%)$ 亿存 在していたが，橋本病，機能六進症などとの関係はなかつた．また石灰沈着は 6 例に，いずれも硬化癌に認 められた。一般に甲状腺小葉間結合織は増加の傾向をしめしていた。

（9）検索例 320 例のうち甲状腺以外の悪性腫煌で剖検された症例は 119 例（37.1\%）で，潜在性甲状腺癌 との重複例が23例 $(19.3 \%)$ 亿認められた.

(10) 甲状腺癌は他臓器の癌腫発生頻度と比較すると少なくはなく，しかも顕微鏡学的検索によつて始めて 
発見されるような微小ないわゆる潜在性癌が意外に多いととを知つた。

潜在性甲状腺癌は病理組織学的に明らかに浸潤增殖しており，転移をおてしてくるであろう潜在力も具備 しているものと考えられる。したがつて甲状腺組織の検索に当つては十分な臨床病理学的精査が必要である と考光る.

本論文の要旨は, 第25回日本癌学会総会, 昭和 42 年度甲状腺同好会において発表および第27回癌学会総会 で追加発表した。

稿を終るに臨み，貴重な材料を睗わつた岩手県立中央病院病理部長田島達郎博土に感謝いたします。

\section{Explanation of Figures}

Gross (Fig. 2-3) and microscopic (Fig. 4-10) findings of latent carcinoma of the thyroid

Fig. 2. Gray mass in surface of right lobe shows primary carcinoma, measuring $12 \mathrm{~mm}$. in its greatest diameter. (KSN. 175).

Fig. 3. The small scar-like lesion in the left central lobe shows primary carcinoma, measuring 2.2 $\mathrm{mm}$. in its greatest diameter. (KSN. 26).

Fig. 4. Papillary adenocarcinoma : shows marke d follicular structure. H.E. (SN. 2021).

Fig. 5. Follicular adenocarcinoma : shows marked follicular structure. H.E. (SN. 1865).

Fig. 6. Trabecular carcinoma : shows throughout entire parenehyma. H.E. (KSN. 191).

Fig. 7. Nonencapsulated sclerosing carcinoma : Sclerosing papillary foci and afibrous lesion mingled with adjacent thyroid parenchyma. H.E. (SN. 1742).

Fig. 8. Nonencapsulated sclerosing carcinoma : Latent sclerosing carcinoma shows the marked infiltration in adjacent thyroid. H.E. (SN. 2055).

Fig. 9. Encapsulated sclerosing carcinoma : shows marked papillary structure. H.E. (SN. 2711).

Fig. 10. Encapsulated sclerosing carcinoma : Follicular sclerosing carcinoma, encapsulated type. H.E. (SN. 1897).

\section{文献}

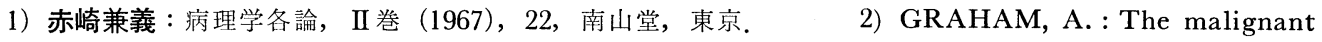
thyroid, Proc. Inter-State Post-Grad. M. Assemb. North America 1927, $3: 264$, (1928). 3) WILSON, L.B. : Ann. Surg, $74: 129$, (1921). 4) 矢川寬一 : 最新医学, $22: 1400$, (1967)。 5) 藤森正雄：外科治療, $18: 71,(1968)$. 6) WOZENKRAFT, P., F.W. Jr. FOOTE and E.L. FRAZELL. : Cancer, $1: 574$ ，(1948). 7) 赤崎兼義 : 手術，14:66，(1960). 8) 平間仁一, 梶田 昭. 肥後直樹, 抗酸菌病研究雑誌, $15: 152$, (1960). 99 ) WOOLNER, L.B., et al. : J. clin. Endocr, 20 : 89, (1960). $\quad$ 10) REED, R.J., B.J. RUSSIN and E.T. KREMENT : J.A.M.A., 196 : 233, (1966). 11) GOETSCH, E. : Ann. Surg, $118: 843$, (1943). 12) HAZARD, J.B. : Lab. Invest, $9: 86$, (1960). 13) MINDER. W.H. : Schweiz. med. Wchnschr, $82: 393$, (1952). 14) KLINGK, G.H. and T. WINSHIP : Cancer, $8: 701$, (1955). 15$)$ HELLWIG, C.A. : Am. J. Glin. Path, $5:$ 103, (1935). $\quad$ 16) SILVERBERG, S.G. and R.A. VIDONE : Ann. Surg, 164 : 291, (1966). 17) HARLAND, W.A. : J. clin. Endocr, $24: 580$, (1964). 18) HULL, O.H. : Arch. Path, $59: 291$, (1955). 19) HAZARD, J.B., G., Jr. GRILE and W.S. DEMPSY : J. Clin. Endocr, $9: 1216$, (1949). 20) BATSAKIS, J.G., R.H. NISHIYAMA and L.R. RIGH : Arch. Path, 69 : 493, (1960). 21) WOOLNER, L.B., O.H. BEAHRS., B.M. BLAGK., W.M. MCCONAHEY and F.R. KEATING : Amer. J.Surg, $102: 354$, (1951). 22) 矢川寬一: 癌の臨床, 10 : 


$$
\text { 高 橋論 文附図（その1） }
$$

2

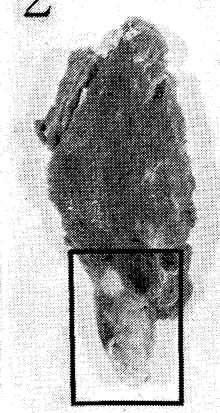

3

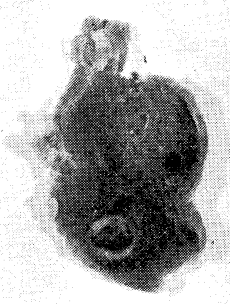

TH 175 .
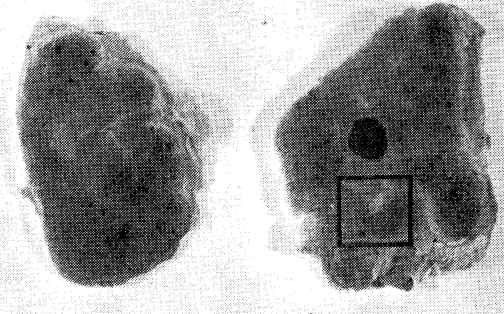

TH 26.

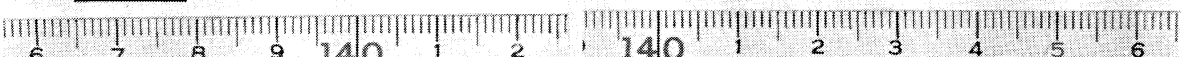
ต

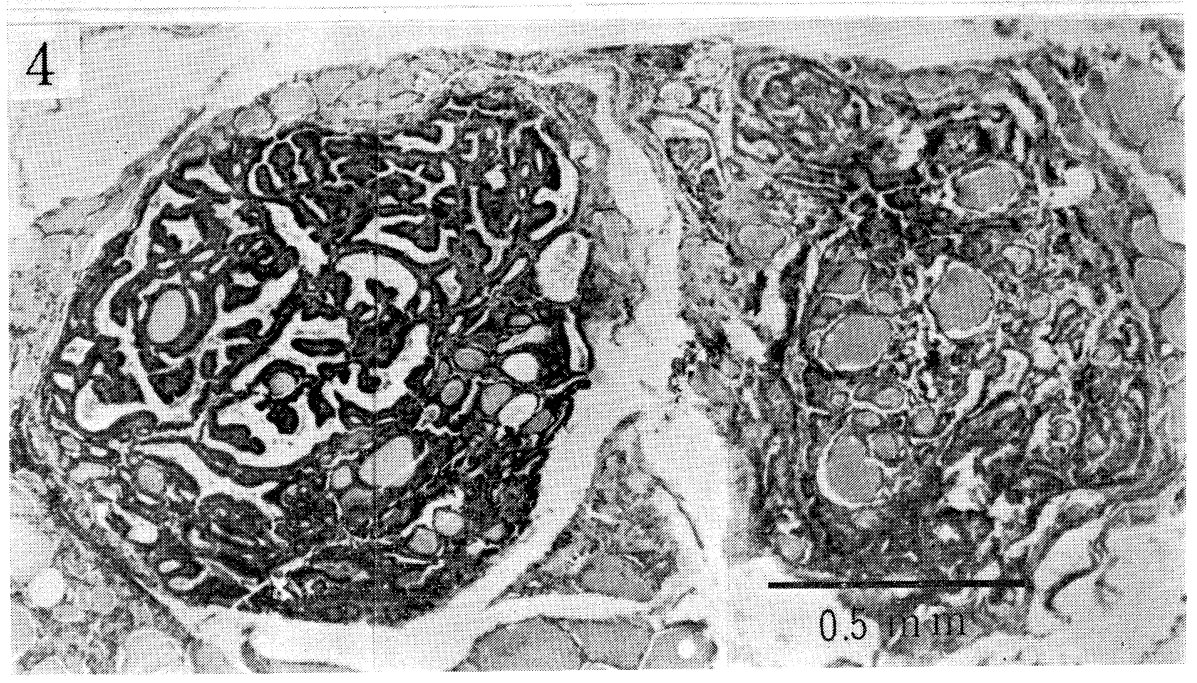




$$
\text { 高 橋 論 文附図（その2） }
$$
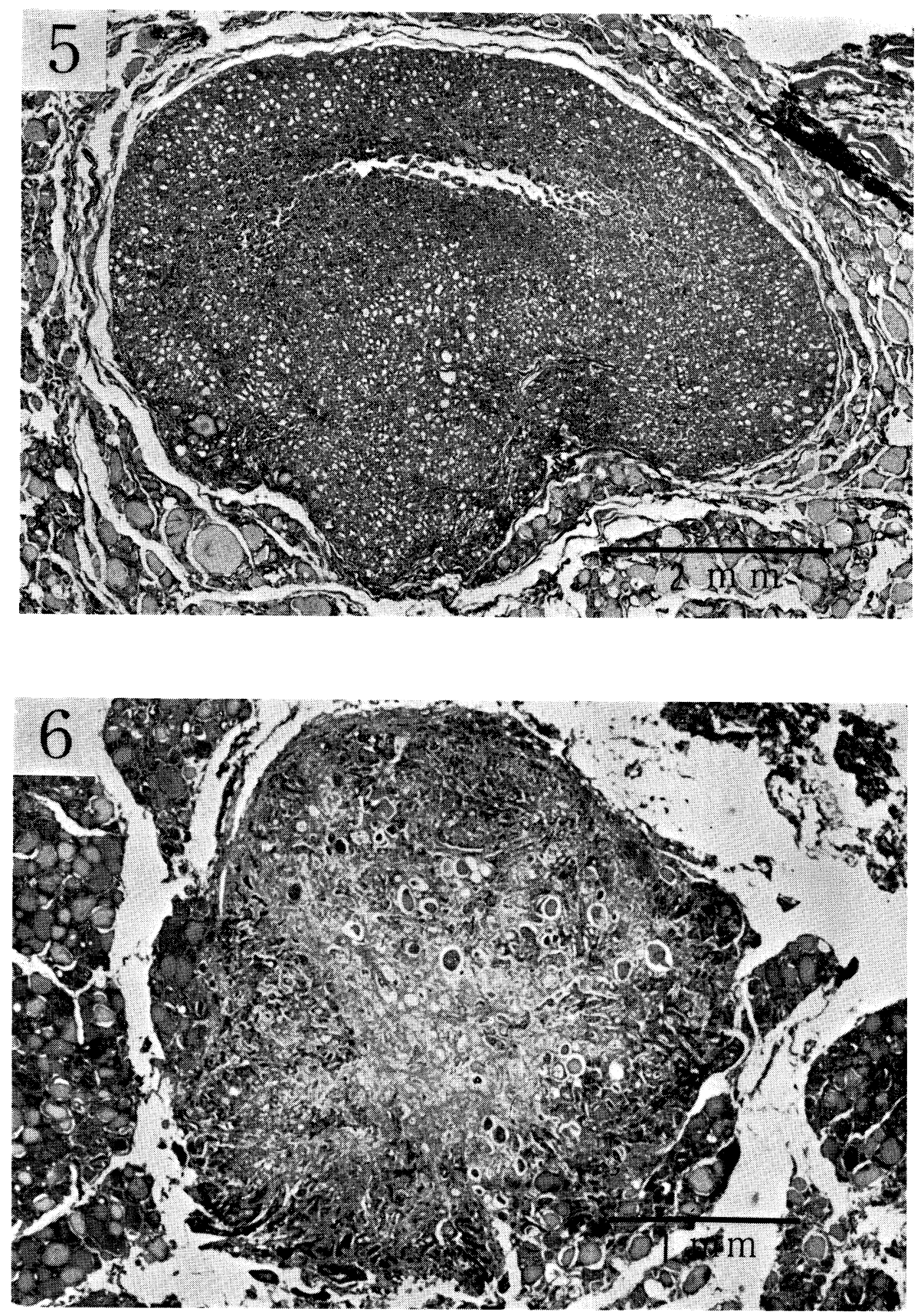


$$
\text { 高橋 論 文附図（その3） }
$$
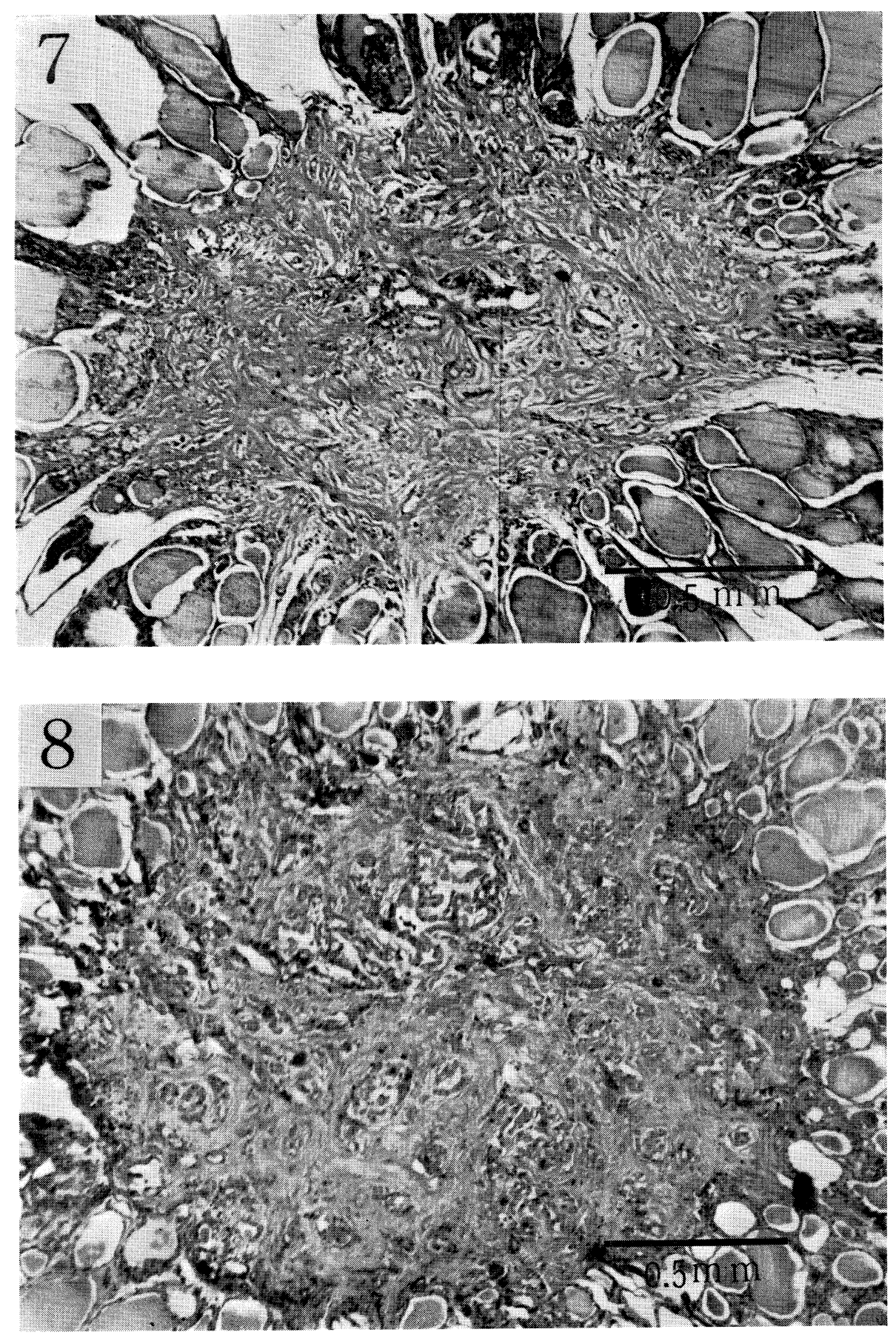
高 橋 論 文 附 図（その4）
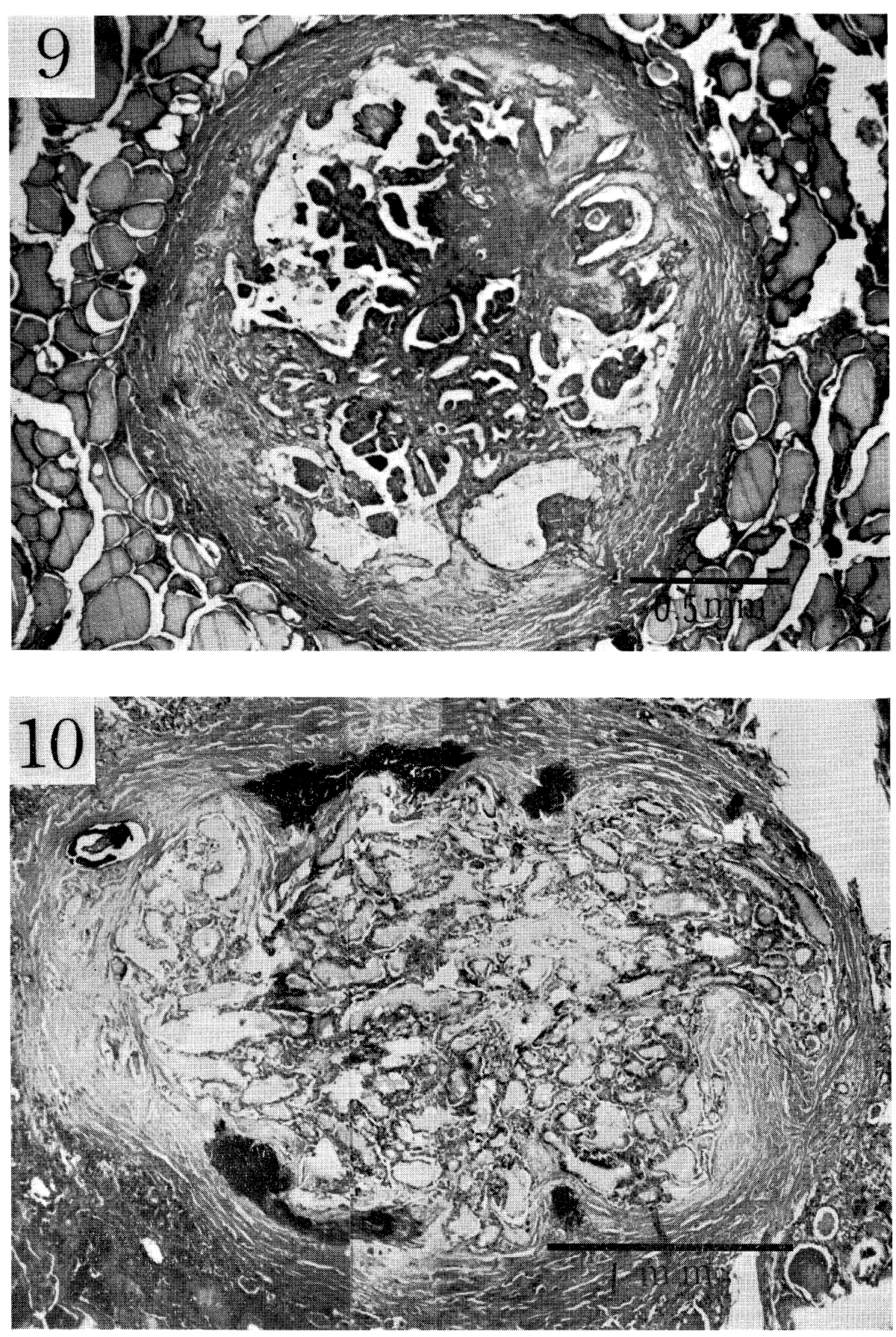
843, (1964).

23）桑田雪雄：日内分泌会誌，42：145，(1966).

24）矢川寛一: 癌の臨床, 特

集号 : 104, (1965).

25) KLINCK, G.H. andT.WINSHIP : Cancer, $12: 656$, (1959).

26)

UNDERWOOD, C.R., L.V. ACKERMAN and C. ECKERT : Surgery, $43: 610$, (1958). 27) BATSAKIS, J.G. : Univ. Michigan med. Bull, $22: 530$, (1956). $\quad 28)$ GRILE, G. Jr. and E.R. FISHER : Cancer, $6: 57$, (1953). 29) KLINGK. G.H., Jr : New York State J. Med, $49: 302$, (1949). 30) SILLIPHANT,W.M., G.H. KLINGK and M.S. LEVITIN : Cancer, 17 : 513, (1964). 31) SCHLESINGER, H.J., S.L. GARGILL and I.H. : J.A.M.A., $110: 1638,1938$. RTENSEN, J.D., L.B. WOOLNER and W.A. BENNET : J. clin. Endocr, $15: 1270$, (1955). 33) MORTENSEN, J.D., L.B. WOOLNER and W.A. BENNET : Am. Coll. Surgeons clin. Cong. (40th), Proc. S. Forum, $4: 659$ ，(1954). 34）笹野伸昭, 大内謙二 : 日病会誌, $49: 733$, (1960). 35) SAMPSON, R.J., C.R. KEY, 岡 久雄, G.R. BUNGHER and 飯島宗一 : 日本癌学会総会記事, $27: 189$, (1968). 36) RUSSELL, W.O., M.L. GLARK and E.C. WHITE : Cancer, 16 : 1425, (1963). 37) FRAZELL, E.L. and F.W. JR. FOOTE : J. clin. Endocr, $9: 1023$, (1949). 38) CRILE, G. JR., J.H. MCNAMARA and J.B. HAZARD : Surg. Gynec. Obstet, $109: 315$, (1959). 39) HAZARD, J.B., et al : A.M.A. Arch. Path, $59: 502$, (1955). 40) BEAHRS, O.H. and L.B. WOOLNER : Surg. Gynec. \& Obst, $108: 43$, (1959). 41) GIKAS, P.W., S.S. LABOW., W. DIGIULIO and J.E. FINGER : Cancer, $20: 2100$, (1967). 42) 藤本吉秀, 岡 厚, 内田久則 : 外科, $29: 1580$, (1967). 43) BILLROTH, C.A.T. : WARREN (44) より引用. 44) WARREN, S. and O. GATES : Amer. J. Cancer, $16: 1358$, (1932). 45) 赤崎兼義, 若狭治毅, 石館卓三: 日本臨床, $19: 1543$, (1961). 46) PIGKREN, J.W. : N.Y. J. Med., 64: 95, (1963). 47) MOERTEL, C.G. : Cancer, $14: 221$, (1961). $\quad 48)$ SHIMAOKA, K., S. TAKEUCHI and J.W. PIGKREN : Gancer, $20: 1000$, (1967). 49) TAYLOR, H.G. JR. : Amer. J. Gancer, 15 : 2517, (1931). 50) HUBER, H. : Strahrentherapie, $92: 130$, (1953). 